\title{
The Welfare Loss from Differential Taxation of Sectors in Germany
}

\author{
DOINA MARIA RADULESCU \\ MICHAEL STIMMELMAYR
}

CESIFO WORKING PAPER No. 2423

CATEGORY 1: PUBliC FinANCE

OCTOBER 2008

\footnotetext{
An electronic version of the paper may be downloaded

- from the SSRN website: Www.SSRN.com

- from the RePEc website: $\quad$ www.RePEc.org

- from the CESifo website: www.CESifo-group.org/wp
} 


\title{
The Welfare Loss from Differential Taxation of Sectors in Germany
}

\begin{abstract}
In the spirit of Harberger, we apply a dynamic computable general equilibrium (CGE) model and estimate the excess burden stemming from the tax-induced distortion in the allocation of capital across the corporate and the non-corporate sectors in Germany. In doing so, we perform a counterfactual analysis and ask how the allocation of capital across sectors would change compared with a sector-neutral tax system which assures an identical effective tax burden on both sectors. Our estimates suggest that the excess burden per period ranges from 2.0 to 3.6 billion Euros or from about 0.1 to 0.16 per cent of GDP. In present value terms, the excess burden translates to about 104 billion Euros or 4.7 per cent of GDP. In order to identify the impact of the firm's financial behaviour on the size of the emerging excess burden, we perform several sensitivity analyses with regard to debt financing, external equity financing and debt constraints via agency cost.
\end{abstract}

JEL Code: C68, C87, D92, H25.

Keywords: capital income taxation, non-uniform taxation, computable general equilibrium modelling.

\author{
Doina Maria Radulescu \\ Center for Economic Studies and CESifo \\ at the University of Munich \\ Schackstr. 4 \\ 80539 Munich \\ Germany \\ radulescu@Imu.de
}

\author{
Michael Stimmelmayr \\ Center for Economic Studies and CESifo \\ at the University of Munich \\ Schackstr. 4 \\ 80539 Munich \\ Germany \\ stimmelmayr@lmu.de
}

The authors are grateful for the comprehensive support of Christian Keuschnigg concerning the theoretical underpinning and the numerical implementation of the model. We would also like to thank in particular Michael Devereux and the two anonymous referees as well as several participants at the annual conference of the IIPF 2005, EcoMOD 2006 and the APET 2007 for their many insightful comments. 


\section{Introduction}

In nearly all OECD countries - with the exception of only a few countries who installed a full imputation system - the returns of corporate investments are subject to a full or at least partial double taxation, while the returns of investments in unincorporated firms are taxed only once, via the personal income tax of the owner. Nevertheless, in OECD countries corporate firms do face on average a lower effective tax burden compared with non-corporate firms, since the fierce international tax competition has put major downward pressure on the various types of capital taxes. Thus, the effective tax burden on corporate firms has declined, while the effective tax burden on labour income and thus on unincorporated firms has stayed constant or even risen in some countries (DEVEREUX, et al. 2002). Consequently, the question arises whether the efficiency loss caused by the non-uniform tax treatment of corporate and unincorporated firms is a quantitatively important issue. This paper aims to answering the question by taking the German case as an example.

In the spirit of HARBERGER ${ }^{1}$, we apply a dynamic, computable general equilibrium (CGE) model and estimate the excess burden stemming from the tax-induced distortion in the allocation of capital across the corporate and non-corporate sectors in Germany. In doing so, we perform a counterfactual analysis and raise the question how the allocation of capital across sectors would change if a 'sector neutral' tax system is in place. Such a tax system ensures that both incorporated and unincorporated firms are subject to the same tax treatment. The developed CGE model traces the accumulation of capital within each sector from the initial to the final steady state, thus allowing us to compute the excess burden for each single period as well as for the phase of transition as such. The excess burden itself is computed as the amount of 'misallocated' capital times the difference in the marginal product of capital between the corporate and noncorporate sector. Since a firm's financial behaviour has a major impact on its effective tax burden, and consequently on its investment decision, we conduct several sensitivity analyses to identify the effect of different financial equilibria on the size of the excess burden emerging from the unequal taxation of sectors in Germany.

\footnotetext{
${ }^{1}$ The distortive power of corporate taxation was first analysed by HARBERGER in his seminal 1962 and 1966 papers. Following HARBERGER, the corporate tax drives a wedge between the marginal product of the capital of corporate and unincorporated firms such that too little capital is accumulated within the more heavily taxed corporate sector, leading to a shortfall of aggregate output. In the German case, we have to put the cart before the horse since the corporate sector faces a lower effective tax burden compared with non-corporate firms. Accordingly, when earnings are retained, too little capital is accumulated within the German non-corporate sector vis-à-vis the German corporate sector.
} 
Regarding the related literature, there are several studies that deal with the tax-induced change in the organisational form of firms. ${ }^{2}$ The number of articles which quantify the Harberger type of excess burden emerging from the tax-induced distortion in the allocation of capital across sectors is, however, rather limited. Important contributions to the latter strand include the studies of GRAVELLE and KoTLIKOFF (1989 and 1993) who measure the movement of capital between corporate and non-corporate production with respect to the difference between corporate and non-corporate capital taxation. On the basis of a Mutual Production Model, where corporate and non-corporate production are close substitutes and all substitution elasticities equal one, the authors quantify a dead-weight loss amounting to 19 per cent of tax revenues. ${ }^{3}$ Our analysis differs from their work in two respects: First, we assume that corporate and non-corporate productions are perfect substitutes, such that our estimates of the excess burden might turn out to be larger. Second, we also deal with the issue of different financial equilibria like debt vis-à-vis equity finance which are not considered in the above-mentioned studies.

The paper is structured as follows: The subsequent section introduces the theoretical setup of the CGE model and outlines the prevailing tax differential between German incorporated and unincorporated firms. Section three describes the empirical implementation of the CGE model. The conducted simulations and sensitivity analyses are presented in sections four and five while section six concludes.

\section{Theoretical setup of the CGE Model}

The dynamic CGE model applied is a two-country model based on the neoclassical growth theory. ${ }^{4}$ Saving and investment decisions are forward-looking and thus permit consideration of important tax capitalisation effects. The firm sector is divided into corporate $(f=C)$ and unincorporated $(f=N C)$ firms which both aim to maximise their value. The firm's optimal investment and financial behaviour is derived from an inter-temporal investment model with convex adjustment costs and convex agency costs of debt finance. The model therefore mimics the most important behavioural margins at the firm level that are strongly sensitive to the effects

\footnotetext{
${ }^{2}$ The studies by Gordon and MACKIE-Mason $(1994,1997)$, GoOlSbeE $(1998,2004)$, or CARroll and Joulfaian (1997), for instance, provide some evidence that US firms do indeed react to prevailing tax differentials with a shift in their organisational form, even though the estimated response is only small.

${ }^{3}$ If the within-industry substitution elasticity is increased to 10 , the excess burden ranges between 39 and 58 per cent of tax revenues and it can even reach 102 per cent of tax revenues if an elasticity of 30 is assumed.

${ }^{4}$ The complete model documentation is available in RADULESCU (2007) or STIMMELMAYR (2007).
} 
of capital income taxation. The household sector consists of a representative infinitively-living individual which maximises its lifetime utility. ${ }^{5}$

The well-behaved, neoclassical production technology, $Y^{f}=f\left(K^{f}, L^{f}\right)$, relies on capital, $K$, and labour, $L$, as input factors and the price of the output good is normalised to unity. Accounting for adjustment costs of size $J^{f}\left(I^{f}, K^{f}\right)$, which resemble decreasing returns from capital accumulation ${ }^{6}$, as well as labour costs, $w L$, and depreciation of capital, $\delta K$, the net of tax profits, $\pi$, of the representative firm state

$$
\begin{aligned}
\pi_{t}^{f} & =Y_{t}^{f}-J_{t}^{f}-w_{t} L_{t}^{f}-\delta K_{t}^{f}-\left(i_{t}+m^{f}\right) B_{t}^{f}-T_{t}^{P, f}, \\
\text { with } T_{t}^{P, f} & =\tau^{P, f}\left[Y_{t}^{f}-J_{t}^{f}-w_{t} L_{t}^{f}-\delta K_{t}^{f}-\left(i_{t}+m^{f}\right) B_{t}^{f}\right]
\end{aligned}
$$

The expression $\left(i+m^{f}\right) B^{f}$ depicts the cost of debt finance and consists of debt interest, $i B^{f}$, as well as convex agency cost of the size $m^{f} B^{f 7}$. Profits of each firm type are subject to a profit tax, $\tau^{P, f}$, which either represents the corporate tax, $\tau^{P, C}$, or the personal income tax of the firm-owner, $\tau^{P, N C}$. In contrast with unincorporated firms, the distributed and retained profits of corporate firms are taxed twice, first on the corporate level by the corporate tax and second on the shareholder level by the dividend or capital gains tax, respectively. ${ }^{8}$ The optimal investment and financial behaviour of each firm is briefly outlined in the following subsection.

\section{Source of Funds and Investment Behaviour}

Firms in the corporate sector have access to three different sources of finance. They can (1) postpone dividend payment and thus finance their investments by retained earnings, $\left(\pi^{C}-\chi^{C}\right),(2)$ they can rely on new equity injections, $V N^{C}$, or (3) on external capital, $B N^{C}$. Depending on the constellation of tax rates a profit-maximising firm would always choose the least expensive source of finance. In order to prevent debt from being the sole source of finance employed, we introduce convex agency costs of debt, $m=m\left(b^{f}\right)$, which rise whenever the debt equity ratio of a firm, $b^{f}=B^{f} / K^{f}$, increases. From an economic point of view, the agency cost can be justified as

\footnotetext{
${ }^{5}$ We have chosen to represent the household sector as an infinitively-living individual since we mainly focus on the efficiency outcomes rather than on the distributional issues of taxation.

${ }^{6}$ The adjustment cost function, $J(I, K)$, is assumed to be linearly homogeneous in investments, $I$, and capital, $K$, and convex in investments, $J_{I}$ and $J_{I I}>0$. Moreover, the steady-state adjustment costs are assumed to be zero.

${ }^{7}$ The agency costs of debt are discussed below in greater detail.

${ }^{8}$ Even if retained earnings are subject to double taxation, they face a preferential tax treatment if capital gains are taxed on a realisation rather than an accrual basis. According to OECD estimates (OECD 1991), the effective tax burden on capital gains amounts to about 60 per cent of the statutory tax burden.
} 
banks will charge heavily-indebted firms higher agency cost of debt in order to account for the increased risk of bankruptcy. The specification of the convex agency cost function follows STRULIK (2003) and is empirically confirmed for the German case.

Moreover, we introduce an exogenous parameter $\beta$ which determines the share of external equity in total investment funds, $V N^{C}=\beta \cdot I N^{C}{ }^{9}$. This parameter $\beta$ is calibrated according to the ratio of new shares issued by German corporations listed at the German stock exchange for German corporate investments. In 2003 for instance, new share issues of German corporations amounted to 12.2 billion Euro (Deutsches Aktieninstitut 2004) and German corporate investments to 203.1 billion Euro (GERMAN CENTRAL BANK 2007a, b), indicating that a share of 6.0 per cent of German corporate investments was financed by new share issues in 2003. Since the amount of new share issues moves procyclically, we set $\beta$ equal to 7 per cent. The latter represents the medium run average of the fraction of new share issues used as investment funds over the period 1996 to 2003.

When $\beta$ is set equal to one, all corporate investments are financed by new equity injections and hence the model replicates the old view of dividend taxation. If the model is, however, supposed to be in line with the new view of dividend taxation, $\beta$ needs to be set equal to zero, implying that corporate investments are solely financed by retained earnings. ${ }^{10}$ On the basis of the nucleus theory of the firm (SINN, 1991b) the parameter $\beta$ can also be interpreted as a measure which balances the share of immature and mature firms in the economy as a whole. ${ }^{11}$ Hence, the calibration of $\beta=0.07$ implies that Germany is modelled as a rather mature economy with only a small share ( 7 per cent) of immature firms.

Furthermore, we calibrate the firm's financial behaviour in the initial steady-state according to the empirical data provided by the GERMAN CENTRAL BANK (2007a, b). These data suggest an average debt-asset ratio of 41 per cent for corporations and of 59 per cent for unincorporated firms. During the phase of transition, the amount of retained earnings and debt is determined endogenously, while the amount of new share issues is fixed via the exogenous parameter $\beta$.

\footnotetext{
${ }^{9}$ A similar approach for modelling the financial behaviour of corporations is also applied by FEHR (1999).

${ }^{10}$ A survey on the different views on dividend taxation is provided by AUERBACH (2002), SINN (1991a), SøRENSEN (1995) or ZODROW (1991), for instance. Empirical papers which deal with the validity of each of the two views include the studies by Poterba and SumMERs (1983) and AUERBACH and HASSETt (2003 and 2007). None of the latter studies confirms either of the two views but they suggest that both views are valid depending on the growth stage of a corporation.

${ }^{11}$ According to the nucleus theory, immature firms finance their investment expenditures solely by new share issues while mature firms mainly rely on retained earnings as investment funds (SINN, 1991b).
} 
The corporate firm's cost of capital is derived from the firm's maximisation problem (see the Appendix). The cost of capital formula depends on the corporate, dividend and capital gains tax rates as well as on the assumed financial behaviour of the firm.

$$
\begin{aligned}
F_{K}^{C}-\delta & =\frac{r^{V}}{\left(1-\tau^{P, C}\right)\left(1-\tau^{G, C}\right)}\left(1-b^{C}\right)+\left[i+m^{C}\right] b^{C} \\
& +\frac{r^{V}}{\left(1-\tau^{P, C}\right)\left(1-\tau^{G, C}\right)} \beta\left[\frac{\left(1-\tau^{G, C}\right)}{\left(1-\tau^{D, C}\right)}-1\right] .
\end{aligned}
$$

The first term on the r.h.s. of the above equation determines the cost of retained earnings, the second term the cost of debt finance and the third term the cost of new share issues. Accordingly, each unit of investments financed by retained earnings has to earn not only the corporate tax and the capital gains tax but also an additional amount which covers the normal return on firm equity, $r^{V} .^{12}$ The costs of debt finance consist of the interest cost, $i$, and the firm-specific agency cost, $m^{C}$. If new shares are used as a source of funds the marginal investment has to earn a return which is at least as high as the required return on firm equity, $r^{V}$, augmented by the corporate and the dividend tax.

If the marginal investment is financed by a combination of the three possible sources of finance, the cost of capital is determined as the weighted average of these, as given in equation (2). The weight attached to the cost of retained earnings is given by one minus the debt-equity ratio, $\left(1-b^{C}\right)$. The share of debt capital is given by the debt-equity ratio, $b^{C}$, whereas the weight for the cost of external equity is determined by the parameter $\beta .^{13}$

The two potential sources of funds on which unincorporated firms can draw are debt, $B N^{N C}$, and external equity, $V N^{N C}$, such that the cost of capital for the non-corporate firm is given by ${ }^{14}$

$$
F_{K}^{N C}-\delta=\frac{r^{V}}{1-\tau^{P, N C}}\left(1-b^{N C}\right)+\left[i+m^{N C}\right] b^{N C}
$$

The cost of equity as depicted by the first term on the r.h.s. of equation (3), consists of the return on firm equity, $r^{V}$, augmented by the personal income tax of the firm owner, $\tau^{P, N C}$. Hence,

\footnotetext{
${ }^{12}$ Note that the different types of assets are imperfect substitutes within the model. Accordingly, the return to firm's equity, $r^{V}$, may differ from the return to capital (bonds) which is equal to the interest rate $i$.

${ }^{13}$ If the corporate firm relies solely on retained earnings, $b^{C}=\beta=0$, the cost of capital is $\left.F_{K}{ }^{C}-\delta=r^{V} /\left(1-\tau^{P, C}\right)\left(1-\tau^{G, C}\right)\right]$. This corresponds to the well-known result derived under the new view of dividend taxation. In contrast, if new shares are the exclusive source of funds, $b^{C}=0$ and $\beta=1$, the cost of capital formula, $F_{K}{ }^{C}-\delta=r^{V} /\left[\left(1-\tau^{P, C}\right)\left(1-\tau^{D, C}\right)\right]$, depends only on the corporate and the dividend tax rate as predicted by the old view of dividend taxation.

${ }^{14}$ See the Appendix for the derivation of the cost of capital for the non-corporate firm.
} 
only the personal income tax rate drives a wedge between the marginal product of capital and the return on firm equity. The second term on the r.h.s. denotes the cost of debt finance.

Equations (2) and (3) reflect the standard theoretical result that the cost of capital and thus the investment incentives of a firm vary with regard to the underlying financial behaviour (see also AUERBACH (1980 and 2002) for a review on taxation and corporate financial policy). In order to identify to what extent the financial behaviour of firms determines the excess burden resulting from the differential taxation of corporate and non-corporate firms, we perform several sensitivity analyses regarding the amount of debt finance, external equity finance and debt constraints via agency costs.

\section{The Tax Differential across Firms of Different Legal Forms}

The sectoral distinctions in the taxation of incorporated and unincorporated firms are one of the major elements of the German tax system. On the one hand, these differences have resulted from the partial double taxation which applies to German corporate firms. On the other hand, the differences also originate in the one-sided support of small and medium-sized enterprises $(\mathrm{SMEs})^{15}$ which are to a large extent organised like unincorporated firms. Since 82.7 per cent of all German enterprises are organised as sole proprietorships or partnerships - while only 15.8 per cent belong to the corporate sector - it is a stated goal of the German government to provide special benefits for unincorporated companies. ${ }^{16}$

In detail, retained profits of a German corporation are subject to various taxes including the corporate tax, the local trade tax and the solidarity surcharge. Even though the statutory German corporate tax rate amounts to only 25 per cent, the effective tax burden on retained earnings of a German corporation adds up to 38.3 per cent. If corporate firms distribute their profits, the dividend tax additionally applies to half of distributed profits on the shareholder level. According to this half-imputation system, the effective tax burden on distributed corporate profits increases to 52.3 per cent.

\footnotetext{
${ }^{15}$ Small and medium-sized enterprises are interpreted as those having less than 500 employees and an annual turnover not exceeding 500.000 Euro for small firms and 50 million Euro for medium-sized enterprises.

${ }^{16}$ If we look at data on turnover and employment, the importance of non-corporate firms is, however, less significant. In the year 2000, non-corporate firms generated 40.8 per cent of total turnover and employed only 35 per cent of all employees while corporate firms produced 55.1 per cent of total turnover and employed 65 per cent of all employees (own calculations based on GUENTERBERG and WOLTER 2002 and BMF 2004 as well as IAB (INSTITUT FÜR ARBEITSMARKT UND BERUFSFORSCHUNG) data).
} 
A German unincorporated firm is also subject to three different types of taxes, namely the personal income tax of the firm-owner, the local trade tax and the solidarity surcharge. If the owner of the unincorporated firm is subject to the top personal income tax rate of 42 per cent, the effective tax burden on unincorporated profits amounts to 45.7 per cent. ${ }^{17}$

To summarise, a German investor who draws one Euro from an unincorporated investment has to pay 45.7 cent in tax vis-à-vis 38.3 cent in the case of a corporate investment financed by retained earnings. Accordingly, a German corporate firm which pays no dividends faces a preferential tax treatment of 7.4 percentage points compared with a German unincorporated firm. $^{18}$

\section{Empirical Implementation of the CGE Model}

The computational procedure of any numeric CGE model requires the specification of functional forms and the choice of appropriate behavioural parameters and elasticities from the empirical literature. In this context, the calibration implies that the initial steady-state of the model replicates the stationary long-run macroeconomic equilibrium of the considered economy. ${ }^{19}$ All behavioural parameters employed here are standard results in line with the findings of the empirical literature. The most important ones are summarised in Table 1.

Table 1: Behavioural Parameter Values

\begin{tabular}{lc}
\hline Economic depreciation rate (FEHR 1999) & 0.08 \\
Half-life of capital accumulation (in years) (CUMMINS ET AL. 1996) & 8.0 \\
Elasticity of factor substitution (GERMAN CENTRAL BANK 1995) & 0.80 \\
Elasticity of the debt-asset ratio (GORDON and LEE 2001) & 0.36 \\
Labour supply elasticity (FENGE ET AL. 2002, weighted average) & 0.37 \\
Intertemporal elasticity of substitution (FLAIG 1988) & 0.40 \\
\hline
\end{tabular}

The real annual growth rate of the German economy is assumed to be 1.1 per cent, which is, according to BANDHOLZ ET AL (2005), a fair estimate for Germany after re-unification. Economic depreciation reaches 8 per cent of the capital stock and the adjustment speed towards the new

\footnotetext{
${ }^{17}$ This number additionally accounts for the special tax deduction treatment which applies to the local trade tax. ${ }^{18}$ If, however, dividends are paid out, a German corporate firm faces a tax discrimination of 6.6 percentage points vis-à-vis a German unincorporated firm. This special case is analysed in the sensitivity analysis 'no. 4'.

${ }^{19}$ Even though hardly any model is able to reproduce the macroeconomic equilibrium as detailed as provided by the national accounts data, each model should at least reflect the stylised facts of the considered economy.
} 
steady-state is determined by the half-life of investment. As in the study of CUMMINS ET AL. (1996), we take a value of 8.0, implying that during the following 8 years after the policy shock half of the long-run increase in the capital stock is accumulated. ${ }^{20}$

One of the key parameters describing the production side of the economy is the elasticity of substitution between labour and capital. The empirical literature offers extensive evidence of different estimates for this parameter. ${ }^{21}$ According to ROSKAMP (1977), the elasticity of factor substitution for West German industries ranges between 0.3 and 1.3. We choose for the present study to apply a value of 0.8 which is based on estimates by the GERMAN CENTRAL BANK (1995).

For the value of the elasticity of the debt-asset ratio, we follow GORDON and LEE (2001), who estimate that a 10 percentage point decrease in the corporate tax rate leads to a reduction in the debt-asset ratio by about three to four per cent.

The labour supply elasticity is set equal to $0.37 .^{22}$ This value represents an average of the empirical estimates for different age and sex groups found in FENGE ET AL. (2002). Accordingly, the applied value lies within the range of 0.2 and 0.43 which, in the opinion of many economists, are appropriate values for compensated labour supply elasticities for men and women, respectively (FUCHS ET AL. 1998).

Given the fact that the macroeconomic effects of capital income taxation are very sensitive to the choice of the inter-temporal elasticity of substitution in consumption (see KING and REBELO 1990 or SUMMERS 1981), this parameter has to be set with great care. Our value of 0.4 is based on FLAIG's (1988) empirical research for Germany, and is just slightly lower than the values applied for instance by KEUSCHNIGG and DiETZ (2004) or VALKONEN (1999).

\section{Macroeconomic Data}

Table 2 reports the main macroeconomic aggregates for Germany for the year 2004, the medium-run averages for the period 1998-2004 and the aggregates replicated by our CGE model, ifoMOD. The medium-run average is computed over the last six years.

\footnotetext{
${ }^{20}$ To achieve this pattern of the half-life of investment, the adjustment cost parameter is set equal to 2 . Such a value is also applied by VALKONEN (1999) and represents a lower end value of available estimates (see WHITED, 1994).

${ }^{21}$ Most estimates for the elasticity of factor substitution range between 0 and 1, depending on the underlying estimation technique. For instance, the study by CHIRINKO, FAZZARI and MEYER (1999), which is based on panel data, suggests an elasticity of 0.25 , whereas higher values of 0.7 for corporate and 0.5 for non-corporate capital are calculated by JORGENSON and YUN (2001), who apply capital stock data. A survey of these studies is provided by CHIRINKO (2002).

${ }^{22}$ This value reflects a compensated supply elasticity, which characterises the relevant substitution effect between labour and leisure.
} 
Table 2: Replicated Macroeconomic Structure (in Bn. Euro)

\begin{tabular}{lccc}
\hline & \multicolumn{2}{c}{ Germany } & Medium-Run \\
& 2004 & Average & ifoMOD \\
\cline { 2 - 4 } GDP & 2207.2 & 2182.5 & $2207.2^{*}$ \\
Compensation of Employees & 1134.1 & 1147.2 & 1169.8 \\
Private Consumption & 1304.2 & 1285.8 & $1304.2^{*}$ \\
Gross Operating Surplus & 501.8 & 470.3 & 527.1 \\
Depreciation & 328.3 & 324.6 & 397.6 \\
Gross Capital Formation & 381.3 & 429.1 & 460.1 \\
Capital Stock & 6586.3 & 6531.5 & 5680.6 \\
Business Debt & 2096.5 & 2003.8 & 2390.1 \\
Government Debt & 1394.9 & 1364.5 & $1394.9^{*}$ \\
\hline Note:* These values are set exogenously within the model in order to replicate the initial steady-state of the \\
German economy.
\end{tabular}

Source: Destatis (2005), own calculations.

The employment of 42.3 million people is computed as the product of the employment share 0.51 and the total German population of 82.5 million people. ${ }^{23}$ This number also matches the official German labour force data (DESTATIS 2005). To identify the relative sizes of the corporate and non-corporate sector within the economy, we use data from the IAB (INSTITUT FÜR ARBEITSMARKT UND BERUFSFORSCHUNG) and compute a labour share of 65 per cent for the corporate sector. The remaining fraction of 35 per cent of the labour force is thus employed in the non-corporate sector.

\section{Simulation Results}

The numerical approach used to measure the excess burden resulting from the differential taxation of German incorporated and unincorporated firms is based on a counterfactual analysis. We raise the question how the long-run allocation of the economy-wide capital stock between sectors changes, if a sector-neutral tax system with an identical effective tax burden on corporate and non-corporate firms is implemented. In the German case, such a tax system implies that (1) the double taxation of corporate taxation is abolished and (2) an identical profit tax is levied on both corporate and non-corporate profits to ensure the tax system is sector-neutral. ${ }^{24}$

\footnotetext{
${ }^{23}$ We assume there is full employment in the economy.

${ }^{24}$ In addition, the tax rate on interest income is set equal to the tax rate on firm profits in order to assure financial neutrality under this sector-neutral tax system.
} 
Since the uniform profit tax may impede capital accumulation as such, we conduct several simulation scenarios to isolate this special level effect. Under each of these scenarios the uniform profit tax rate is set equal to $30,35,40,45$ and 50 per cent.

The allocation of capital across sectors evolving in the final steady-state under the respective uniform tax rate is taken as a benchmark for the optimal (undistorted) allocation of capital between sectors.

As Table 3 indicates, under the current German tax system - which determines the initial steady-state in our analysis - about 64 per cent of the total capital stock is allocated to the corporate sector and the remaining 36 per cent to the non-corporate sector. After the reform, when the economy reaches the final steady-state, where both types of firms face an identical tax burden, the allocation of capital alters significantly. While the share of capital accumulated within the corporate sector declines, additional capital is accumulated within the non-corporate sector. This difference in the allocation of capital between the initial and the final steady-state provides our measure for the tax-induced distortion in the allocation of capital across sectors in Germany.

Table 3: Change in the Allocation of Capital across Sectors (in \%)

\begin{tabular}{lccccc}
\hline & Scenario 1 & Scenario 2 & Scenario 3 & Scenario 4 & Scenario 5 \\
Uniform Profit Tax & 30 & 35 & 40 & 45 & 50 \\
$\Delta$ Capital Stock & 14.2 & 8.9 & 3.3 & -2.4 & -8.0 \\
Initial Allocation (C/NC) & $63.8 / 36.2$ & $63.8 / 36.2$ & $63.8 / 36.2$ & $63.8 / 36.2$ & $63.8 / 36.2$ \\
Final Allocation (C/NC) & $59.6 / 40.4$ & $58.9 / 41.1$ & $58.2 / 41.8$ & $57.2 / 42.8$ & $56.1 / 43.9$ \\
$\Delta$ Debt-Asset Ratio (C/NC) & $-3.0 /-5.7$ & $-0.6 /-4.1$ & $2.4 /-2.5$ & $6.1 /-0.5$ & $10.7 / 2.0$ \\
\hline
\end{tabular}

Source: Own calculations.

Since the initial steady-state is predetermined by the current German situation, the initial allocation of capital across sectors is the same under each scenario. The percentage change in the overall capital stock varies significantly, however, with the applied uniform profit tax rate. If the latter amounts, for instance, to 30 per cent (Scenario 1) both the corporate and the non-corporate sector face a major tax relief which fosters capital accumulation. In total, the economy-wide capital stock is augmented by 14.2 per cent in the long-run under Scenario 1. If the uniform profit tax is set to 50 per cent, both corporate and non-corporate firms are negatively affected by the increased tax burden, such that the overall long-run capital stock shrinks by 8.0 per cent, as depicted by Scenario 5. 
Furthermore, as can be seen from the above table, the allocation of capital in the final steadystates depends also on the applied uniform tax rate. As the uniform profit tax rate is raised from 30 to 50 per cent, the amount of misallocated capital increases, too. Under Scenario 1, where a uniform profit tax rate of 30 per cent applies, the fraction of misallocated capital amounts to 4.2 per cent. If the uniform profit tax rate is set to 50 per cent the fraction of misallocated capital increases to 7.7 per cent.

This larger shift under a higher uniform profit tax rate can be explained by the change in the relative tax burden of incorporated and unincorporated firms. For instance, under a uniform profit tax rate of 45 per cent (Scenario 4) the corporate firm which was initially subject to an effective tax burden of just 38.3 per cent faces a major tax increase, while the non-corporate firms still enjoy a slight tax reduction of 0.7 percentage points. In order to counteract the major tax increase, the corporate firm adjusts its financial behaviour and increasingly relies on debt finance such that the debt-asset ratio of the representative corporate firm increases by 6.1 per cent. Despite the adjustment in the financial behaviour of corporate firms, the increase in the uniform tax rate hits the corporate sector relatively harder, thus impeding the accumulation of capital within this sector. As a consequence, the fraction of misallocated capital increases with the tax rate.

As shown in the sensitivity analysis, however, the allocation of capital across sectors in the final steady-state hardly depends on the uniform profit tax rate if both types of firm start off with an identical debt-asset ratio in the initial steady-state (see Table 5).

The per period excess burden which results from the differential taxation of German incorporated and unincorporated firms is approximated by multiplication of the amount of misallocated capital within each period by the period-specific difference in the marginal product of capital between the corporate and the non-corporate sector. At this stage, some remarks might be necessary to explain why we do not - in the spirit of Harberger - apply the 'triangular formula' to compute the excess burden. The answer is straightforward: In the case of a pure steady-state comparison, which would resemble a static rather than a dynamic analysis, this approach would be appropriate to approximate the excess burden as the marginal product of capital is a downward sloping function with regard to capital. In the dynamic analysis conducted, however, we account for this decline in the marginal product of capital by re-evaluating the marginal product of capital in each period when the stock of capital within the corporate or non-corporate sector has changed. Similar to the static analysis, the discrepancy in the marginal product of capital will 
diminish from period to period and therewith the excess burden, as the allocation of capital across sectors improves during the phase of transition.

Table 4: Excess Burden (in Bn. Euro)

\begin{tabular}{lccccc}
\hline & Scenario 1 & Scenario 2 & Scenario 3 & Scenario 4 & Scenario 5 \\
Uniform Profit Tax (in \%) & 30 & 35 & 40 & 45 & 50 \\
Excess Burden (per period) & 2.0 & 2.3 & 2.6 & 3.1 & 3.6 \\
PV of EB (persistency) & 82.1 & 92.3 & 104.3 & 119.3 & 138.1 \\
PV of EB (transition) & 25.3 & 28.3 & 32.9 & 39.7 & 49.3 \\
Average interest rate (in \%) & 3.5 & 3.6 & 3.7 & 3.8 & 3.9 \\
\hline
\end{tabular}

Source: Own calculations.

If the excess burden is expressed in monetary terms, the per period excess burden ranges between 2.0 to 3.6 billion Euro, which is equivalent to about 0.1 to 0.16 per cent of GDP. Thus, on the assumption that the current German tax system is not changed (= persistency), the present value (PV) of the excess burden amounts to about 104 billion Euro (Scenario 4) - or 4.7 percent of GDP. ${ }^{25}$ If the German tax system is replaced by a sector-neutral tax system with an equal effective tax burden on incorporated and unincorporated firms (= transition), the present value of the excess burden ranges between 25.3 and 49.3 billion Euro, depending on the size of the uniform profit tax rate in place.

In what follows we look at the evolution of the excess burden and the misallocation of capital over time. During the phase of transition, the stock of capital in the corporate sector shrinks while the one in the non-corporate sectors rises. Therefore, (1) the amount of misallocated capital declines from period to period and (2) the gap between the marginal products of capital diminishes. As a consequence, the resulting excess burden decreases as the allocation of capital across sectors improves from one period to the next. Figure 1 shows the evolution of the excess burden in the course of time. The solid black line depicts the case of a uniform profit tax of 30 per cent and the grey line the case of a uniform profit tax of 50 per cent

In the first period, the excess burden amounts to about 2.0 (or 3.6) billion Euros, respectively and after 8 (or 18) periods it has already declined by almost 50 per cent. Finally, after 60 (or 80) periods the allocation of capital has improved so much that the excess burden has almost vanished.

\footnotetext{
${ }^{25}$ Scenario 4 could be referred to as the reference scenario, as a uniform profit tax rate of 45 per cent seems to be a feasible estimate which could ensure that the government's budget is balanced.
} 
Figure 1: Excess Burden in the Course of Time

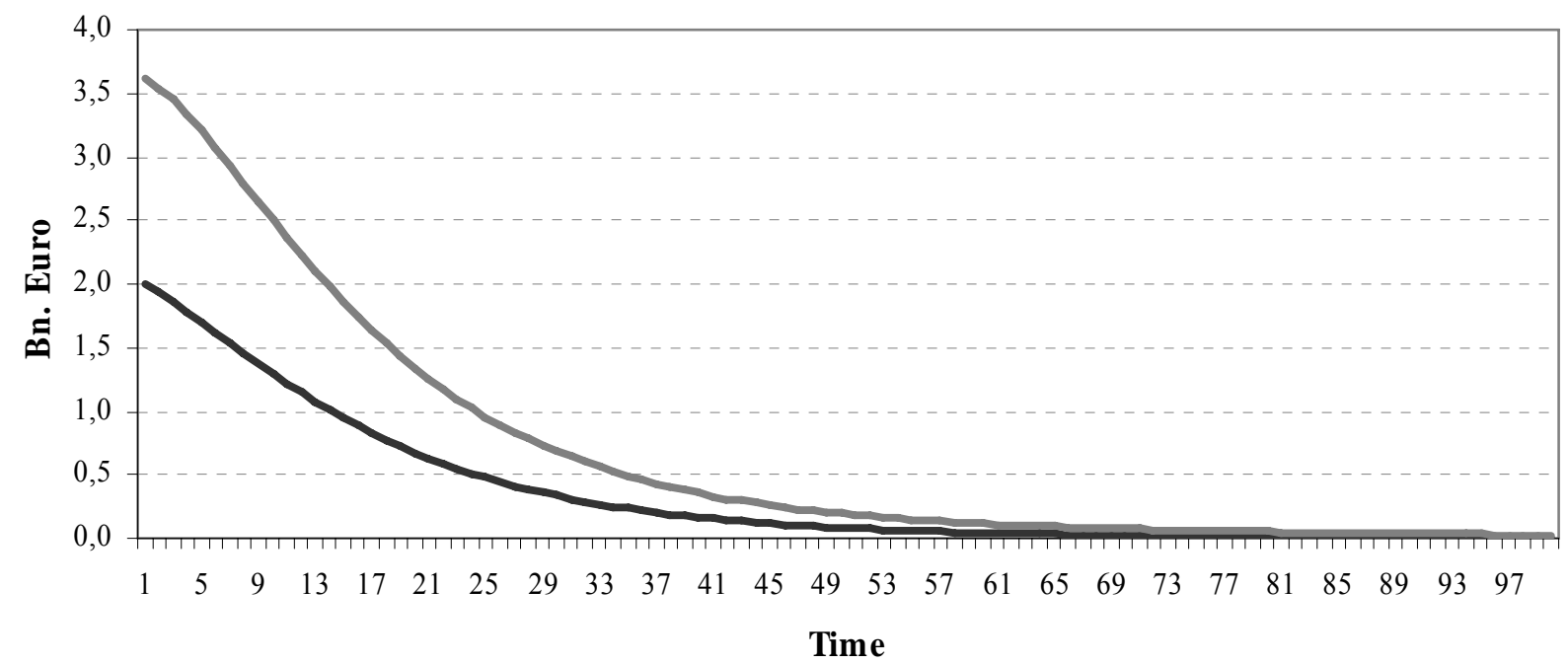

As discussed above, the differential in the effective tax burden and the cost of capital for corporate and non-corporate firms crucially depend on the assumed financial behaviour of corporate and unincorporated firms. In the following sensitivity analysis we therefore investigate to what extent the excess burden is influenced by the financial behaviour of firms.

\section{Sensitivity Analysis}

In the first two sensitivity analyses conducted, we check the robustness of our results with regard to the debt-asset ratio of firms. We start from the assumption that both corporate and noncorporate firms have the same initial debt-asset ratio of 50 or 25 per cent, respectively.

As reported in Table 5, the change in the overall capital stock again hinges decisively on the uniform tax rate applied. The final allocation of capital across sectors, however, is scarcely affected by the uniform tax rate if both firm types start off with an identical debt-asset ratio. Irrespective of whether we apply a uniform profit tax rate of just 30 per cent, or a higher one of 50 per cent, the distortion in the allocation of capital amounts in each case to about 5.5 per cent of the economy-wide capital stock, if a uniform debt-asset ratio of 50 per cent is assumed.

Since the fraction of misallocated capital is almost constant in sensitivity analyses one and two, the excess burden arising under the non-uniform taxation of sectors changes only slightly. If we set the debt-asset ratio for both firm types to 50 per cent, the per period excess burden amounts to 
approximately 2 billion Euro. Accordingly, the present value of the excess burden ranges between 70 and 80 billion Euro. ${ }^{26}$

Table 5: Sensitivity Analysis with regard to the Debt-Asset Ratio

\begin{tabular}{|c|c|c|c|c|c|}
\hline & Scenario 1 & Scenario 2 & Scenario 3 & Scenario 4 & Scenario 5 \\
\hline Uniform Profit Tax (in \%) & 30 & 35 & 40 & 45 & 50 \\
\hline \multicolumn{6}{|c|}{ Sensitivity Analysis 1: Debt-Asset-Ratio: 50\% (each Firm Type) } \\
\hline$\Delta$ Capital Stock & 13.9 & 8.8 & 3.5 & -2.1 & -7.8 \\
\hline Initial Allocation (C/NC) & $65.8 / 34.2$ & $65.8 / 34.2$ & $65.8 / 34.2$ & $65.8 / 34.2$ & $65.8 / 34.2$ \\
\hline Final Allocation (C/NC) & $60.1 / 39.9$ & $60.1 / 39.9$ & $60.2 / 39.8$ & $60.3 / 39.7$ & $60.5 / 39.5$ \\
\hline Excess Burden (p.p., bn. €) & 2.0 & 1.98 & 1.95 & 1.90 & 1.83 \\
\hline PV of EB (persistency, bn. €) & 80.8 & 79.0 & 76.5 & 73.4 & 69.7 \\
\hline \multicolumn{6}{|c|}{ Sensitivity Analysis 2: Debt-Asset-Ratio: 25\% (each Firm Type) } \\
\hline$\Delta$ Capital Stock & 15.6 & 9.6 & 3.1 & -3.6 & -10.6 \\
\hline Initial Allocation (C/NC) & $66.2 / 33.8$ & $66.2 / 33.8$ & $66.2 / 33.8$ & $66.2 / 33.8$ & $66.2 / 33.8$ \\
\hline Final Allocation (C/NC) & $57.5 / 42.5$ & $57.5 / 42.5$ & $57.6 / 42.2$ & $57.6 / 42.4$ & $57.7 / 42.3$ \\
\hline Excess Burden (p.p., bn. €) & 4.4 & 4.4 & 4.4 & 4.3 & 4.3 \\
\hline PV of EB (persistency, bn. $€$ ) & 178.4 & 176.2 & 173.4 & 170.0 & 166.7 \\
\hline
\end{tabular}

Source: Own calculations.

If both firm types finance only 25 per cent of new investments via debt, the fraction of misallocated capital is slightly higher as in the previous case and amounts to 8.5 per cent. Since a larger share of capital is allocated to the sector with a lower marginal product of capital, it is not surprising that the resulting per period excess burden is also slightly higher in this second sensitivity analysis resulting in the present value of the excess burden.

The increased shifting of capital under sensitivity analysis 2 is because of the effective tax burden of corporate and non-corporate firms. Since the debt-asset ratio is limited to 25 per cent, the non-corporate firm cannot reduce its tax burden by relying more heavily on debt finance as compared with the base scenario. The initial tax differential between corporate and non-corporate firms is therefore larger, which explains the larger fraction of misallocated capital.

A second class of sensitivity analyses is devoted to the controversy of the new versus the old view of dividend taxation. In particular, we check the robustness of our results with respect to the change in the amount of new share issues used as investment funds.

\footnotetext{
${ }^{26}$ The discrepancy in the present value calculation is because of the different discount rates applied under each scenario. The discount rate varies between the different scenarios since it is determined endogenously in the twocountry model and hinges on the economy-wide capital stock.
} 
As discussed in Section 3, to get a proxy for the amount of new share issues utilised as investment funds, $\beta$, we compute the ratio of annually-issued shares of German corporations and the annual investment expenditures of German corporations. In 1991, when Germany reached the peak of its new economy boom, the amount of new share issues was more than twice as large as the computed 10-year average of 7 per cent. We therefore set the exogenous parameter $\beta$ to 14 per cent in the third sensitivity analysis. This change has hardly any impact on the initial distribution of capital across sectors (see Table 3). Nevertheless, it affects the allocation of capital in the final steady-state.

Table 6: Sensitivity Analysis with regard to the Amount of New Share Issues

\begin{tabular}{lccccc}
\hline & Scenario 1 & Scenario 2 & Scenario 3 & Scenario 4 & Scenario 5 \\
Uniform Profit Tax (in \%) & 30 & 35 & 40 & 45 & 50 \\
& Sensitivity Analysis 3: New Share Issues: $14 \%$ & & \\
$\Delta$ Capital Stock & 15.3 & 10.2 & 4.5 & -1.2 & -6.9 \\
Initial Allocation (C/NC) & $63.5 / 36.3$ & $63.5 / 36.3$ & $63.5 / 36.3$ & $63.5 / 36.3$ & $63.5 / 36.3$ \\
Final Allocation (C/NC) & $61.6 / 38.4$ & $61.0 / 39.0$ & $60.3 / 39.7$ & $59.4 / 40.6$ & $58.3 / 41.7$ \\
Excess Burden (p.p., bn. $€$ ) & 1.1 & 1.5 & 1.9 & 2.4 & 3.1 \\
PV of EB (persistency, bn. $€$ ) & 45.6 & 59.1 & 74.5 & 93.4 & 116.7 \\
& Sensitivity Analysis $4:$ New Share Issues: $100 \%$ & & 7.4 & -0.1 \\
$\Delta$ Capital Stock & 28.7 & 22.4 & 14.9 & $56.6 / 43.4$ & $56.6 / 43.4$ \\
Initial Allocation (C/NC) & $56.6 / 43.4$ & $56.6 / 43.4$ & $56.6 / 43.4$ & 56.6 & $67.7 / 32.2$ \\
Final Allocation (C/NC) & $73.9 / 26.1$ & $72.5 / 27.5$ & $71.4 / 28.7$ & $69.8 / 30.2$ & 35.1 \\
Excess Burden (p.p., bn. $€$ ) & 54.8 & 50.5 & 46.8 & 41.9 & 1279.1 \\
PV of EB (persistency, bn. $€$ ) & 2151.2 & 1937.4 & 1754.3 & 1542.1 & \\
\hline Source: Own calculations. & & & & & \\
\end{tabular}

Source: Own calculations.

As shown in Table 6, less capital is shifted from the corporate to the non-corporate sector indicating a less severe misallocation of capital across sectors - if firms use twice as much external equity for financing investments. This numerical result confirms the theoretical prediction. If a corporate firm relies more heavily on new share issues instead of retained earnings its effective tax burden increases since, according to the present German tax law, corporate distributions are subject to dividend tax while capital gains are tax-exempt. If the effective tax burden of the corporate firm increases, the difference between the effective tax burden of German incorporated and unincorporated firms diminishes and therewith the taxinduced misallocation of capital across sectors. As a consequence, the per period excess burden 
as well as the present value of the excess burden is in any case smaller than the results presented in Table 4.

The fourth sensitivity analysis represents the old view of dividend taxation in its pure form, meaning that all new investments are financed by new share issues only. The old view of dividend taxation implies under the present German tax law a partial double taxation of corporate profits since half of distributed profits are subject to the personal income tax of the shareholder. ${ }^{27}$ Under the old view therefore the effective tax burden on corporations is larger than the effective tax burden on non-corporate firms, such that too little capital is accumulated within the corporate sector, which is also implicitly shown by the figures in Table 6. Compared with the benchmark case (Table 3), less capital (only 56.6 per cent instead of 63.8 per cent) is allocated to the corporate sector in the initial steady-state as a result of the higher tax burden on German corporations. Moreover, the higher tax burden on corporate firms impedes the accumulation of capital within this sector. This implicitly means that under the counterfactual analysis even a larger fraction of capital should be accumulated within the corporate sector.

Accordingly, under the old view scenario, almost three times as much capital is misallocated compared with the benchmark case (see Scenario 4 of Sensitivity Analysis 4 in Table 6 and Scenario 4 in Table 3). This larger distortion in the allocation of capital explains the higher excess burden as well. Moreover, as can be seen from Table 6, the excess burden declines with the applied uniform profit tax rate. A uniform profit tax rate of just 30 per cent implies a larger tax relief for corporate firms compared with non-corporate firms. ${ }^{28}$ The tax-induced incentive to accumulate capital in the corporate sector is therefore stronger. As opposed to this, a uniform profit tax rate of 50 per cent represents only a slight tax cut for corporate firms and accordingly incentives are only low to accumulate additional capital in the corporate sector. Consequently, the distortion in the allocation of capital and the excess burden diminish with the applied uniform profit tax rate.

The last sensitivity analysis is performed with respect to the agency cost of debt. This variable is of particular importance as it also influences a firm's preference for debt or equity finance. Our calibration of the agency cost function is based on GORDON and LEE (2001). The authors estimate an elasticity of the debt-asset ratio with regard to the corporate tax rate of 0.36 . For our model this implies that the effective cost of debt exceeds the interest cost by around 1 percentage point

\footnotetext{
${ }^{27}$ This partial double taxation does not arise under the new view since capital gains are tax-exempt in Germany.

${ }^{28}$ Since we assume here that at the margin all profits are distributed and thus, as discussed in Section 3, we have a double taxation of corporate profits.
} 
since the agency costs amount to 1.3 and 1.1 per cent for corporate and non-corporate firms respectively.

Table 7: Sensitivity Analysis with regard to the Agency Cost of Debt

\begin{tabular}{lccccc}
\hline & Scenario 1 & Scenario 2 & Scenario 3 & Scenario 4 & Scenario 5 \\
Uniform Profit Tax (in \%) & 30 & 35 & 40 & 45 & 50 \\
\multicolumn{5}{c}{ Sensitivity Analysis 5: Debt Elasticity is doubled by half (for both firms) } & \\
$\Delta$ Capital Stock & 13.9 & 8.4 & 3.2 & -2.4 & -7.7 \\
Initial Allocation (C/NC) & $63.9 / 36.1$ & $63.9 / 36.1$ & $63.9 / 36.1$ & $63.9 / 36.1$ & $63.9 / 36.1$ \\
Final Allocation (C/NC) & $59.5 / 40.4$ & $59.0 / 41.0$ & $58.3 / 41.7$ & $57.5 / 42.5$ & $56.5 / 43.5$ \\
Excess Burden (p.p., bn. $€$ ) & 1.9 & 2.2 & 2.5 & 2.8 & 3.3 \\
PV of EB (persistency, bn. $€$ ) & 78.7 & 86.3 & 96.8 & 108.4 & 124.2 \\
\hline
\end{tabular}

Source: Own calculations.

This last sensitivity analysis shows the effects of increased agency costs on the excess burden. As the agency costs are determined by the elasticity of the debt-asset ratio with respect to the corporate tax, the 50 per cent higher debt elasticity translates into agency costs of 2.0 and 1.6 per cent for incorporated and unincorporated firms respectively. As can be seen from the above table, the results are robust with respect to the agency costs. Compared with the benchmark case presented in Table 4, the excess burden is only slightly smaller even though the agency costs are 50 per cent higher than in the benchmark scenario.

\section{Conclusion}

The aim of the paper was to shed light on the question whether the different tax burden on corporate and non-corporate firms is indeed an issue since it might cause a considerable excess burden. Using the German case as an example, we have shown that the differential taxation of incorporated and unincorporated firms does lead to efficiency losses. In addition to what is already known from the literature, we show that the excess burden crucially depends on the source of finance of the investments undertaken by corporate and non-corporate firms.

In contrast with the standard Harberger result, however, we find that too much capital is accumulated in the corporate sector and too little in the non-corporate sector, since the corporate sector in Germany faces a preferential tax treatment vis-à-vis the non-corporate sector, on the assumption that investments in the former sector are financed by retained earnings at the margin. 
The per period excess burden resulting from this misallocation of capital across sectors amounts to about 0.1 to 0.16 per cent of GDP, depending on the underlying uniform tax rate assumed in each scenario of the counterfactual analysis. Even if these numbers seem to be rather small at first sight, given that this kind of excess burden persists as long as corporate and non-corporate firms are subject to different tax rules, in present value terms, the excess burden reaches even 5.4 per cent of GDP or about 120 billion Euro.

Nevertheless, the results depend to a large extent on the assumed financial behaviour of firms. If firms are, for instance, debt-constrained, as is the case in the second sensitivity analysis, the excess burden arising per period is only slightly higher and amounts to about 0.2 per cent of GDP. In present value terms, however, this difference is quite significant, since the present value of the excess burden rises to about 170 billion Euro or 7.7 per cent of GDP. The limited use of debt prevents especially non-corporate firms from reducing their tax burden by relying more heavily on debt financing. Thus, the initial tax differential between corporate and non-corporate firms is larger, resulting in the share of misallocated capital.

Regarding new shares as the marginal source of finance, we find that a slight increase in the share of external equity finance has only a small impact on the estimated excess burden. As opposed to this, if firms rely up to $100 \%$ on new share issues as investments funds, as predicted by the old view of dividend taxation, the arising excess burden is more than ten times larger compared with the benchmark case. This outcome is because of the partial double taxation of German corporate profits under the old view, which implies that too little capital is accumulated within the corporate sector. Accordingly, in the counterfactual analysis where both corporate and non-corporate firms face the same tax burden, even more capital should be accumulated in the corporate sector. 


\section{Appendix - Inter-temporal Optimisation of Firms:}

To solve the inter-temporal optimisation problem of the representative firm of either sector, we start with the expression of net of tax profits, namely

$$
\pi^{f}=\left(1-\tau^{P, f}\right)\left[Y^{f}-J^{f}-w L^{f}-\delta K^{f}-\left(i_{t}+m^{f}\right) B_{t}^{f}\right]
$$

Recalling the flow of funds equation for corporate firms, $(1-\beta) I N^{C}=\left(\pi^{C}-\chi^{C}\right)+B N^{C}$, as well as the expression for new share issues, $V N^{C}=\beta I N^{C}$, and combining it with the above profit equation (A.1), we derive an explicit expression denoting dividends of corporate firms

$$
\chi^{C}=\left(1-\tau^{P, f}\right)\left[Y^{f}-J^{f}-w L^{f}-\delta K^{f}-\left(i_{t}+m^{f}\right) B_{t}^{f}\right]+B N^{C}-(1-\beta) I N^{C} .
$$

For non-corporate firms the flow of funds identity states $I N^{N C}=V N^{N C}+B N^{N C}$ since $\chi^{N C}=\pi^{N C}$ is true. Moreover, no dividend tax applies to non-corporate firms, $\tau^{D, N C}=0$.

In equilibrium, firm equity yields a net of tax return of $r^{V}$ which comprises net of tax dividend income and net of tax capital gains. ${ }^{29}$

$$
r_{t}^{V} V_{t}^{f}=\left(1-\tau^{D, f}\right) \chi_{t}^{f}+\left(1-\tau^{G, f}\right)\left[G V_{t+1}^{f}-V_{t}^{f}-V N_{t}^{f}\right]
$$

If we keep in mind that a firm can only maximise its end of period value, $V_{t}^{e, f}=\left(1+r^{e q u, f}\right) V_{t}^{f}$ with $r^{e q u, f}=r^{V} /\left(1-\tau^{G, f}\right)$, the maximisation problem of the respective firm type states

$$
\begin{aligned}
V^{e, f}\left(K_{t}^{f}, B_{t}^{f}\right) & =\max _{L^{f}, I^{f}, B N^{f}}\left[\chi_{t}^{f}+\frac{G}{1+r_{t+1}^{e q u, f}}\right] V^{e, f}\left(K_{t+1}^{f}, B_{t+1}^{f}\right) \\
\text { s.t. } \quad G K_{t+1}^{f} & =I_{t}^{f}+(1-\delta) K_{t}^{f}, \\
G B_{t+1}^{f} & =B N_{t}^{f}+B_{t}^{f} .
\end{aligned}
$$

Moreover, we define the shadow prices of capital $q_{t}^{e, f} \equiv d V_{t}^{e, f} / d K_{t}^{f}$ and debt $\lambda_{t}^{e, f} \equiv d V_{t}^{e, f} / d B_{t}^{f}$, respectively, ${ }^{30}$ as well as the following three tax parameters for corporate and non-corporate firms

\footnotetext{
${ }^{29}$ If the financial market investment and the investment in firm equity are assumed to be perfect substitutes, the investors' arbitrage condition requires that the net of tax return on firm equity equals the net of tax return earned at the financial market, $r^{V}=\left(1-\tau^{i}\right) i$. The variable $\tau^{i}$ denotes the tax on interest income and $i$ the gross interest rate.
} 

(a) $\gamma^{D, C}=\frac{\left(1-\tau^{P, C}\right)\left(1-\tau^{D, C}\right)}{\left(1-\tau^{G, C}\right)}$,
$\gamma^{D, N C}=\frac{\left(1-\tau^{P, N C}\right)}{\left(1-\tau^{G, N C}\right)}$,
(b) $\gamma^{I, C}=\frac{\left(1-\tau^{D, C}\right)}{\left(1-\tau^{G, C}\right)}(1-\beta)+\beta$
$\gamma^{I, N C}=1$,
(c) $\Omega^{I, C}=\frac{\left(1-\tau^{D, C}\right)}{\left(1-\tau^{G, C}\right)}$,
$\Omega^{I, C}=1$.

such that the optimality conditions with regard to the control variables labour, $L^{f}$, investment, $f^{f}$, and new debt, $B N^{f}$, are given by
(a) $L_{t}^{f}: \quad w_{t}=F_{L, t}^{f}$,
(b) $I_{t}^{f}: q_{t+1}^{f}=\left(1+r_{t+1}^{e q u, f}\right)\left[\gamma^{D, f} J_{t}^{f}+\gamma^{I, f}\right]$,
(c) $\mathrm{BN}_{t}^{f}: \lambda^{f}{ }_{t+1}=-\left(1+r_{t+1}^{e q u, f}\right) \Omega^{f}$.

and the envelope conditions with regard to the stock variables are given by

$$
\begin{aligned}
& \text { (a) } q_{t}^{f}=\gamma^{D, f}\left[F_{K}^{f}-J_{K}^{f}+m_{f}^{\prime} b_{f}^{2}\right]-\left(\gamma^{D, f}-\gamma^{I, f}\right) \delta+\frac{q_{t+1}^{f}}{1+r_{t+1}^{e q u, f}}(1-\delta) \\
& \text { (b) } \lambda_{t}^{f}=\gamma^{D, f}\left[-m_{f}^{\prime} b_{f}-m_{f}-i\right]+\frac{\lambda_{t+1}^{f}}{1+r_{t+1}^{e q u, f}} .
\end{aligned}
$$

The marginal product of capital can finally be derived by combining equations (A.7a) and (A.6b)

$$
F_{K}^{f}-\delta=r_{t}^{e q u, f} \frac{\gamma^{I, f}}{\gamma^{D, f}}-\left(m_{f}^{\prime} b_{f}\right) b_{f} .
$$

To obtain an equation representing optimal debt policy, equations (A.7b) and (A.6c) need to be combined, resulting in

$$
\frac{r_{t}^{V}}{\left(1-\tau^{G, f}\right)}=\frac{\gamma^{I, f}}{\Omega^{f}}\left[m_{f}^{\prime} b_{f}+m_{f}+i\right] .
$$

Accordingly, the 1.h.s. of the above equation represents the cost of equity while the r.h.s. denotes the cost of debt financing. The optimal debt level is achieved if the costs of internal financing are

\footnotetext{
${ }^{30}$ The shadow prices determine the increase in the value of the objective function resulting from a marginal increase in the stock variables' capital or debt.
} 
equal to the cost of external financing. If the last two equations (A.8) and (A.9) are combined, the marginal product of capital can be expressed as the weighted sum of the cost of equity capital and external capital, where the debt-asset ratio, $b^{f}$, serves as weighting factor

$$
F_{K}^{f}-\delta=\frac{r_{t}^{e q u, f}}{\gamma^{D, f}}\left[\gamma^{I, f}-\Omega^{f} b_{f}\right]+\left[i+m_{f}\right] b_{f}
$$

These equations enable us to determine the cost of capital which influences the investment decision of the firm as well as the cost of equity and debt finance which determine a firm's financing behaviour. 


\section{References}

- Auerbach, A. J. (1980): "Taxation and Corporate Financial Policy", NBER Working Paper W0243, Washington D.C.

- Auerbach, A. J. (2002): "Taxation and Corporate Financial Policy", in A. J. Auerbach and M. Feldstein (eds.), Handbook of Public Economics III, pp. 1251-1292, Elsevier, Amsterdam.

- Auerbach, A. J. and K. A. Hassett (2003): "On the Marginal Source of Investment Funds", Journal of Public Economics, 87/1, pp. 205-232.

- Auerbach, A. J. and K. A. Hassett (2007): "The 2003 Dividend Tax Cuts and the Value of the Firm: An Event Study", in A. Auerbach, J. Hines, and J. Slemrod, (eds.), Taxing Corporate Income in the 21st Century, pp. 93-126, Cambridge University Press, Cambridge, UK.

- Bandholz H., G. Flaig and J. Mayr (2005): "Wachstum und Konjunktur in OECD Ländern: Eine langfrisitge Perspektive", ifo Schnelldienst 58/4, pp. 28-36.

- BMF, Bundesministerium der Finanzen (2004a): "Die Steuerpolitik der Bundesregierung ist gezielte Mittelstandsförderung", November 2004, http://www.bundesfinanzministerium.de / Anlage27575/Gezielte \% 20Mittelstandsförderung.pdf.

- Carroll, R. and D. Joulfaian (1997): "Taxes and Corporate Choice of Organizational Form", U.S. Department of the Treasury, OTA Paper 73.

- Chirinko, R. S. (2002): "Corporate Taxation, Capital Formation, and the Substitution Elasticity Between Labor and Capital", CESifo Working Paper No. 707.

- Chirinko, R.S., S.M. Fazzari and A.P. Meyer (1999): "How Responsive is Business Capital Formation to Its User Cost? An Exploration with Micro Data", Journal of Public Economics 74, pp. 53-80.

- Cummins, J.G., K. A. Hassett and G.R. Hubbard (1996): "Tax Reform and Investment: A Cross-Country Comparison", Journal of Public Economics 62, pp. 237-273.

- Destatis, Statistisches Bundesamt (2005): Statistisches Jahrbuch 2005 für die Bundesrepublik Deutschland, Wiesbaden.

- Deutsches Aktieninstitut (2004): DAI Factbook, Frankfurt am Main.

- Devereux, M.P., R. Griffith and A. Klemm (2002): "Corporate Income Tax Reforms and International Tax Competition", Economic Policy, pp. 451-495.

- Fehr, H. (1999): Welfare Effects of Dynamic Tax Reforms, Mohr-Siebeck, Tübingen.

- Fenge, R., S. Übelmesser and M. Werding (2002): "Second-Best Properties of Implicit Social Security Taxes: Theory and Evidence", CESifo Working Paper No. 743.

- Flaig, G. (1988): "Einkommen, Zinssatz und Inflation - Ein Beitrag zur Erklärung von Konsumwachstumsschwankungen", in: G. Bombach, B. Gahlen, A.E. Ott, (eds.), Geldtheorie und Geldpolitik, pp. 291-314, Mohr Siebeck, Tübingen. 
- Fuchs, V. R., A. B. Krueger and J. M. Poterba (1998): "Economists' Views about Parameters, Values and Survey Results in Labor and Public Economics", Journal of Economic Literature 36, pp. 1387-1425.

- German Central Bank (1995): "Das Produktionspotential in Deutschland und seine Bestimmungsfaktoren", Monatsbericht 47/ 8, pp. 41-57.

- German Central Bank (2007a): Ergebnisse der gesamtwirtschaftlichen Finanzierungsrechnung für Deutschland, 1991 bis 2006, Statistische Sonderveröffentlichungen 4, Frankfurt am Main.

- German Central Bank (2007b): Verhältnisszahlen aus Jahresabschlüssen deutscher Unternehmen von 2000 bis 2004, Statistische Sonderveröffentlichungen 6, Frankfurt am Main.

- Goolsbee, A. (1998): "Taxes, Organizational Form, and the Deadweight Loss of the Corporate Income Tax", Journal of Public Economics, 69, pp. 143-152.

- Goolsbee, A. (2004): "The Impact of the Corporate Income Tax: Evidence from State Organizational form Data", Journal of Public Economics, 88, pp. 2283-2299.

- Gordon, R. H. and Y. Lee (2001): "Do Taxes Affect Corporate Debt Policy? Evidence from US Corporate Tax Return Data", Journal of Public Economics 81, pp. 195-224.

- Gordon, R. H. and J. MacKie-Mason (1994): "Tax Distortions to the Choice of Organizational Form", Journal of Public Economics 55/2, pp. 279-306.

- Gordon, R. H. and J. MacKie-Mason (1997): "How Much Do Taxes Discourage Incorporation?", Journal of Finance 52/2, pp. 477-505.

- Gravelle, J. G. and L. J. Kotlikoff (1989): "The Incidence and Efficiency Costs of Corporate Taxation when Corporate and Noncorporate Firms Produce the Same Good", Journal of Political Economy 97/41, pp. 749-780.

- Gravelle, J. G. and L. J. Kotlikoff (1993): "Corporate Tax Incidence and Inefficiency when Corporate and Noncorporate Goods are Close Substitutes", Economic Inquiry 31/2, pp. 501516.

- Guenterberg, B. and H.-J. Wolter (2002): "Unternehmensgrößenstruktur in Deutschland nach Wirtschaftsbereichen und Rechtsformen", Unternehmensgrößenstatistik 2001/2002 - Daten und Fakten, Institut fuer Mittelstandsforschung, Bonn.

- Harberger, A. C. (1962): "The Incidence of the Corporation Income Tax", Journal of Political Economy 70, pp. 215-240.

- Harberger, A. C. (1966): "Efficiency Effects of Taxes on Income from Capital" in Krzyzaniak Marian (ed.), Effects of Corporation Income Tax, Wayne State University Press, Detroit.

- Jorgenson, D. W. and K.-Y. Yun (2001): Lifting the Burden: Tax Reform, The Cost of Capital, and U.S. Economic Growth, MIT Press, Cambridge, MA. 
- Keuschnigg, C. and M. Dietz (2004), "A Swiss Dual Income Tax For More Neutrality in Company Taxation", Swiss Journal of Economics and Statistics 140, pp. 483-519.

- $\quad$ King, R.G. and S.T. Rebelo (1990): "Public Policy and Economic Growth: Developing Neoclassical Implications", Journal of Political Economy 98, pp. 127-150.

- OECD (1991): Taxing Profits in a Global Economy: Domestic and International Issues, Paris.

- Poterba, J. M. and L. H. Summers (1983): "Dividend Taxes, Corporate Investment, and 'Q"', Journal of Public Economics 22, 135-167.

- Radulescu, D. M. (2007): CGE Models and Capital Income Tax Reforms. The Case of a Dual Income Tax for Germany, Springer, Heidelberg.

- Roskamp, K. A. (1977): "Labor Productivity and the Elasticity of Factor Substitution in West German Industries", The Review of Economics and Statistics 59, pp. 366-371.

- Sinn, H.-W. (1991a): "Taxation and the Cost of Capital: The 'Old' View, the 'New' View, and Another View" in: D. Bradford, (ed.), Tax Policy and the Economy 5, pp. 25-54, MIT Press, Cambridge, MA.

- Sinn, H.-W. (1991b): "The Vanishing Harberger Triangle", Journal of Public Economics 45, pp. 271-300.

- Sørensen, P. B. (1995): "Changing Views of the Corporate Income Tax", National Tax Journal 48/2, pp. 279-295.

- Stimmelmayr, M. (2007): Fundamental Capital Income Tax Reforms: Discussion and Simulation using ifoMOD, Mohr Siebeck, Tübingen.

- Strulik, H. (2003): "Supply-Side Economics of Germany's Year 2000 Tax Reform: A Quantitative Assessment", German Economic Review 4, pp. 183-202.

- Summers, L. H. (1981): "Tax Policy, the Rate of Return and Savings", NBER Working Paper No. 995, Cambridge, MA.

- Valkonen, T. (1999): The Finnish Corporate and Capital Income Tax Reform: A General Equilibrium Approach, ETLA, Helsinki.

- Whited, T. N. (1994): "Problems with Identifying Adjustment Costs From Regressions of Investment on Q", Economic Letters 46, pp. 339-344.

- Zodrow, G. R. (1991): "On the 'Traditional' and 'New' View of Dividend Taxation", National Tax Journal 44, pp. 497-509. 


\section{CESifo Working Paper Series}

for full list see www.cesifo-group.org/wp

(address: Poschingerstr. 5, 81679 Munich, Germany, office@cesifo.de)

2361 Francisco Alvarez-Cuadrado and Ngo Van Long, A Permanent Income Version of the Relative Income Hypothesis, July 2008

2362 Gabrielle Demange, Robert Fenge and Silke Uebelmesser, Financing Higher Education and Labor Mobility, July 2008

2363 Alessandra Casarico and Alessandro Sommacal, Labor Income Taxation, Human Capital and Growth: The Role of Child Care, August 2008

2364 Antonis Adam, Manthos D. Delis and Pantelis Kammas, Fiscal Decentralization and Public Sector Efficiency: Evidence from OECD Countries, August 2008

2365 Stefan Voigt, The (Economic) Effects of Lay Participation in Courts - A Cross-Country Analysis, August 2008

2366 Tobias König and Andreas Wagener, (Post-)Materialist Attitudes and the Mix of Capital and Labour Taxation, August 2008

2367 Ximing Wu, Andreas Savvides and Thanasis Stengos, The Global Joint Distribution of Income and Health, August 2008

2368 Alejandro Donado and Klaus Wälde, Trade Unions Go Global!, August 2008

2369 Hans Gersbach and Hans Haller, Exit and Power in General Equilibrium, August 2008

2370 Jan P.A.M. Jacobs and Jan-Egbert Sturm, The Information Content of KOF Indicators on Swiss Current Account Data Revisions, August 2008

2371 Oliver Hülsewig, Johannes Mayr and Timo Wollmershäuser, Forecasting Euro Area Real GDP: Optimal Pooling of Information, August 2008

2372 Tigran Poghosyan and Jakob de Haan, Determinants of Cross-Border Bank Acquisitions in Transition Economies: A Latent Class Analysis, August 2008

2373 David Anthoff and Richard S.J. Tol, On International Equity Weights and National Decision Making on Climate Change, August 2008

2374 Florian Englmaier and Arno Schmöller, Reserve Price Formation in Online Auctions, August 2008

2375 Karl Farmer, Birgit Friedl and Andreas Rainer, Effects of Unilateral Climate Policy on Terms of Trade, Capital Accumulation, and Welfare in a World Economy, August 2008

2376 Monika Bütler, Stefan Staubli and Maria Grazia Zito, The Role of the Annuity's Value on the Decision (Not) to Annuitize: Evidence from a Large Policy Change, August 2008 
2377 Inmaculada Martínez-Zarzoso, The Impact of Urbanization on $\mathrm{CO}_{2}$ Emissions: Evidence from Developing Countries, August 2008

2378 Brian Roberson and Dmitriy Kvasov, The Non-Constant-Sum Colonel Blotto Game, August 2008

2379 Ian Dew-Becker, How Much Sunlight Does it Take to Disinfect a Boardroom? A Short History of Executive Compensation Regulation, August 2008

2380 Cécile Aubert, Oliver Falck and Stephan Heblich, Subsidizing National Champions: An Evolutionary Perspective, August 2008

2381 Sebastian Buhai, Miguel Portela, Coen Teulings and Aico van Vuuren, Returns to Tenure or Seniority?, August 2008

2382 Erkki Koskela and Jan König, Flexible Outsourcing, Profit Sharing and Equilibrium Unemployment, August 2008

2383 Torberg Falch and Justina AV Fischer, Does a Generous Welfare State Crowd out Student Achievement? Panel Data Evidence from International Student Tests, September 2008

2384 Pedro Gomes and François Pouget, Corporate Tax Competition and the Decline of Public Investment, September 2008

2385 Marko Koethenbuerger, How Do Local Governments Decide on Public Policy in Fiscal Federalism? Tax vs. Expenditure Optimization, September 2008

2386 Ronald McKinnon and Gunther Schnabl, China's Exchange Rate Impasse and the Weak U.S. Dollar, September 2008

2387 Yan-Leung Cheung, Yin-Wong Cheung and Alan T.K. Wan, A High-Low Model of Daily Stock Price Ranges, September 2008

2388 Louis Eeckhoudt and Harris Schlesinger, Changes in Risk and the Demand for Saving, September 2008

2389 Carsten Hefeker and Blandine Zimmer, Uncertainty and Fiscal Policy in an Asymmetric Monetary Union, September 2008

2390 Jay Pil Choi and Byung-Cheol Kim, Net Neutrality and Investment Incentives, September 2008

2391 Marcel Gérard, Financing Bologna, the Internationally Mobile Students in European Higher Education, September 2008

2392 Annette Alstadsæter and Knut Reidar Wangen, Corporations' Choice of Tax Regime when Transition Costs are Small and Income Shifting Potential is Large, September 2008 
2393 António Afonso and Christophe Rault, 3-Step Analysis of Public Finances Sustainability: the Case of the European Union, September 2008

2394 Betsey Stevenson and Justin Wolfers, Economic Growth and Subjective Well-Being: Reassessing the Easterlin Paradox, September 2008

2395 Bernhard Eckwert and Itzhak Zilcha, Private Investment in Higher Education: Comparing Alternative Funding Schemes, September 2008

2396 Øystein Foros, Hans Jarle Kind and Jan Yngve Sand, Slotting Allowances and Manufacturers' Retail Sales Effort, September 2008

2397 Mohammad Reza Farzanegan, Illegal Trade in the Iranian Economy: Evidence from a Structural Model, September 2008

2398 Olivier Bos, Charity Auctions for the Happy Few, September 2008

2399 Robert S. Chirinko and Debdulal Mallick, The Marginal Product of Capital: A Persistent International Puzzle, September 2008

2400 Ben D'Exelle and Arno Riedl, Elite Capture, Political Voice and Exclusion from Aid: An Experimental Study, September 2008

2401 Torben M. Andersen and Joydeep Bhattacharya, On Myopia as Rationale for Social Security, September 2008

2402 Fabienne Llense, French CEO Compensations: What is the Cost of a Mandatory Upper Limit?, September 2008

2403 Valentina Bosetti, Carlo Carraro, Alessandra Sgobbi and Massimo Tavoni, Delayed Action and Uncertain Targets. How Much Will Climate Policy Cost?, September 2008

2404 Robert G. Chambers, Rolf Färe, Shawna Grosskopf and Michael Vardanyan, Generalized Quadratic Revenue Functions, September 2008

2405 Leonidas Enrique de la Rosa, Overconfidence in a Career-Concerns Setting, September 2008

2406 Marcus Drometer and Johannes Rincke, The Design of Political Institutions: Electoral Competition and the Choice of Ballot Access Restrictions in the United States, September 2008

2407 Markku Lanne and Helmut Lütkepohl, Stock Prices and Economic Fluctuations: A Markov Switching Structural Vector Autoregressive Analysis, September 2008

2408 Thomas L. Brewer, International Energy Technology Transfers for Climate Change Mitigations, September 2008

2409 Alexander Kemnitz, Native Welfare Losses from High Skilled Immigration, September 2008 
2410 Xavier Vives, Strategic Supply Function Competition with Private Information, September 2008

2411 Fabio Padovano and Roberto Ricciuti, The Political Competition-Economic Performance Puzzle: Evidence from the OECD Countries and the Italian Regions, September 2008

2412 Joan Costa-Font and Mireia Jofre-Bonet, Body Image and Food Disorders: Evidence from a Sample of European Women, September 2008

2413 Thorsten Upmann, Labour Unions - To Unite or to Separate?, October 2008

2414 Sascha O. Becker and Ludger Woessmann, Luther and the Girls: Religious Denomination and the Female Education Gap in $19^{\text {th }}$ Century Prussia, October 2008

2415 Florian Englmaier and Stephen Leider, Contractual and Organizational Structure with Reciprocal Agents, October 2008

2416 Vittorio Daniele and Ugo Marani, Organized Crime and Foreign Direct Investment: The Italian Case, October 2008

2417 Valentina Bosetti, Carlo Carraro, Alessandra Sgobbi and Massimo Tavoni, Modelling Economic Impacts of Alternative International Climate Policy Architectures. A Quantitative and Comparative Assessment of Architectures for Agreement, October 2008

2418 Paul De Grauwe, Animal Spirits and Monetary Policy, October 2008

2419 Guglielmo Maria Caporale, Christophe Rault, Robert Sova and Anamaria Sova, On the Bilateral Trade Effects of Free Trade Agreements between the EU-15 and the CEEC-4 Countries, October 2008

2420 Yin-Wong Cheung and Daniel Friedman, Speculative Attacks: A Laboratory Study in Continuous Time, October 2008

2421 Kamila Fialová and Ondřej Schneider, Labour Market Institutions and their Effect on Labour Market Performance in the New EU Member Countries, October 2008

2422 Alexander Ludwig and Michael Reiter, Sharing Demographic Risk - Who is Afraid of the Baby Bust?, October 2008

2423 Doina Maria Radulescu and Michael Stimmelmayr, The Welfare Loss from Differential Taxation of Sectors in Germany, October 2008 